\title{
The increase in energy efficiency of residential buildings of military towns
}

\author{
Olga Gamayunova ${ }^{1,{ }^{*}}$, Anton Radaev ${ }^{1}$, and Mikhail Petrichenko ${ }^{1}$, and Ekaterina Dmitrieva ${ }^{2}$ \\ ${ }^{1}$ Peter the Great St. Petersburg Polytechnic University, Polytechnicheskaya, 29, Saint-Petersburg, \\ 195251, Russia \\ ${ }^{2}$ Moscow State University of Civil Engineering, 26, Yaroslavskoye Shosse, Moscow, 129337, Russia
}

\begin{abstract}
Most of the residential multi-apartment buildings in use in our country do not meet modern regulatory requirements for the level of thermal protection of external enclosing structures. Such buildings require renovation. The objects of the research are residential buildings of KPD-4570 series, which are a typical series of buildings for military towns. The options for improving the energy efficiency of residential construction with the help of selection of heaters that meet the requirements for thermal protection of buildings are proposed. The method of calculating the discounted payback period for insulation costs is presented.
\end{abstract}

\section{Introduction}

Today new military towns are equipped in all military districts of our country. All new facilities have high technical characteristics and are equipped with modern systems that ensure reliable storage and operation of weapons and military equipment.

However, one should not forget about the already existing buildings and structures of military towns, which are characterized by low-rise and relatively cheap materials. Most of them were built in 60-90 years of the last century (and even earlier), when, of course, energy efficiency requirements did not exist.

\section{Materials and Methods}

\subsection{Housing of military towns}

A military town is a complex of buildings and structures located on one land plot and used for quartering military units of the garrison and for military, workers and employees of the Armed Forces of the Russian Federation.

The main model series of residential buildings for the construction of military towns is the KPD-4570 series (see Ошибка! Источник ссылки не найден., Ошибка! Источник ссылки не найден.2).

\footnotetext{
*Corresponding author: gamayunova_os@spbstu.ru
} 


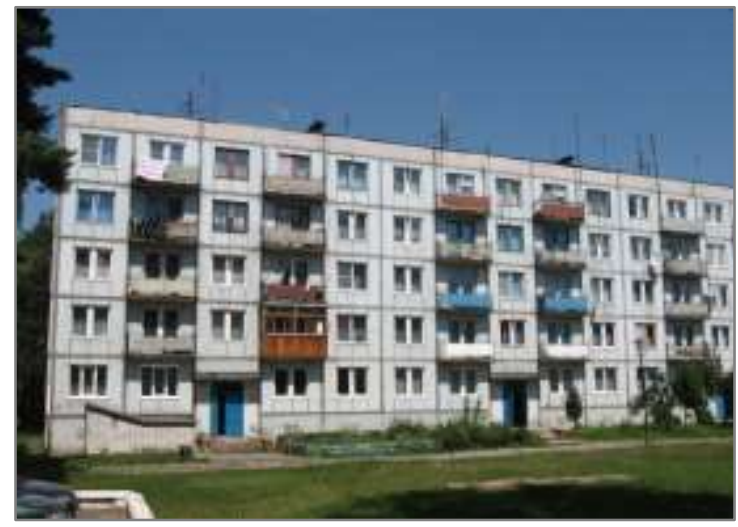

Fig. 1. Houses of KPD- 4570 series.

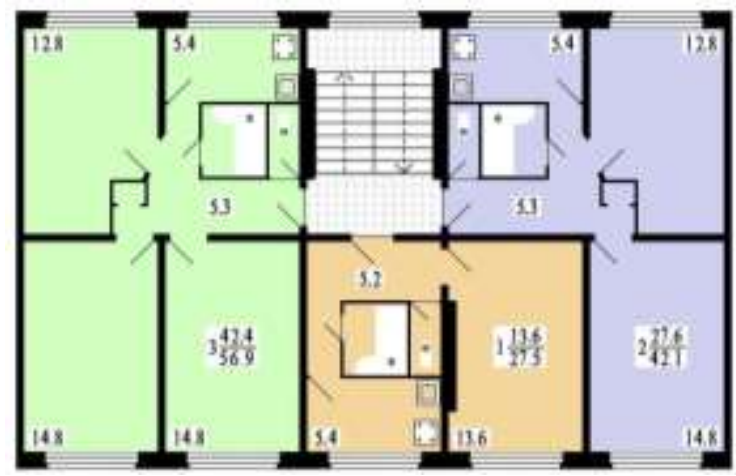

Fig. 2. Variants of apartment layouts in the houses of KPD- 4570 series

The main drawbacks of the houses of this series are low ceilings, lack of elevators and mu-piping, small kitchens and hallways, walk-through entrances, etc. Among the advantages are a separate bathroom, as well as tambour attached to the entrances in some of KPD-4570 series. The main characteristics of the houses of KPD-4570 series are presented in Table 1.

Table 1. Main characteristics of the houses of KPD-4570 series.

\begin{tabular}{ll}
\hline Main characteristics & Description \\
\hline Regions of construction & The territory of the former USSR, Eastern Europe \\
Construction technology & Panel house \\
Construction period & $1957-1990$ \\
Number of floors & 5 \\
Ceiling height & $2.5 \mathrm{~m}$ \\
Bathrooms & separate in all apartments \\
Garbage chute & no \\
Elevators & no \\
Number of apartments per floor & 3 \\
& external - depending on location and modification - three- \\
Walls and cladding & layer, mounted or cassette, bearing frame - transverse and lon- \\
& gitudinal central walls \\
\hline
\end{tabular}


Depending on the location and modification in KPD-4570 series of residential buildings, various types of exterior walls were changed. For example, in the 1989 modification, the outer walls of the building are made of keramzit concrete panels (see Fig. 3, Fig. 4, Table 2) with a density of $1000 \mathrm{~kg} / \mathrm{m}$ with a total thickness of $400 \mathrm{~mm}$. The building itself is a multiapartment 5-storey residential building with a cold attic. The building has 5 entrances and 75 apartments ( 3 per floor). In the underground part of the building there is an unheated basement. The building has a rectangular shape and dimensions in terms of $11.8 \times 80.5 \mathrm{~m}$ and a height of $16.3 \mathrm{~m}$.

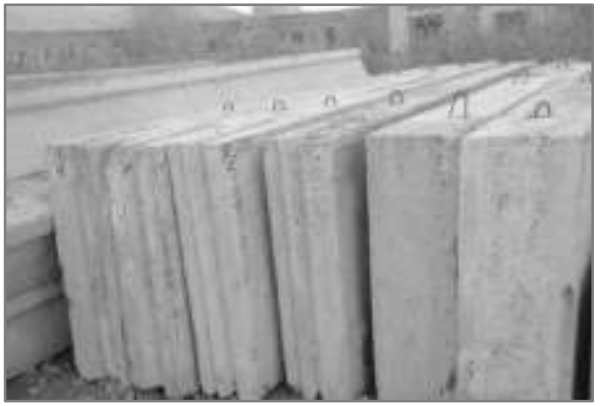

Fig. 3. Wall keramzit concrete panels.

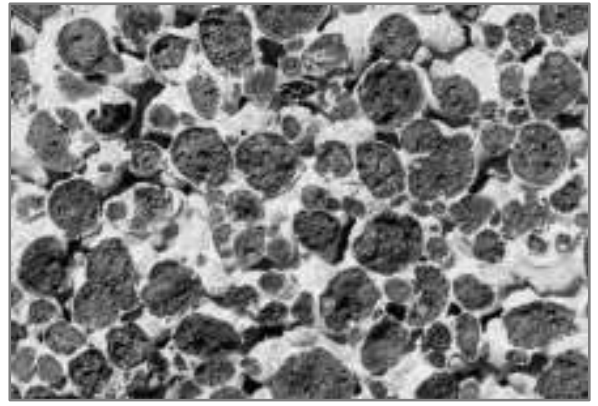

Fig.4. Structure of keramzit concrete.

Table 2. Thermotechnical characteristics of external walls of houses of KPD-4570 series

\begin{tabular}{lllll}
\hline $\begin{array}{l}\text { Layer } \\
\text { No }\end{array}$ & Material & $\begin{array}{l}\text { Layer thickness } \\
(\boldsymbol{\delta}), \mathbf{m}\end{array}$ & $\begin{array}{l}\text { Density }(\boldsymbol{\rho}), \\
\mathbf{k g} / \mathbf{m}^{\mathbf{3}}\end{array}$ & $\begin{array}{l}\text { Coefficient of thermal } \\
\text { conductivity }(\boldsymbol{\lambda}), \mathbf{W} /\left(\mathbf{m} \cdot{ }^{\circ} \mathbf{C}\right)\end{array}$ \\
\hline 1 & Keramzit concrete & 0.4 & 1000 & 0.25 \\
\hline
\end{tabular}

\subsection{Thermotechnical calculation of enclosing structures}

In 2012, SP 50.13330.2012 "Thermal protection of buildings" was put into effect, which is used in the design of thermal protection of buildings under construction or reconstructed, in which a certain temperature and humidity conditions need to be maintained.

Using the above methodology, the thermal characteristics of the material of the wall construction of houses of KPD-4570 series, as well as the climatic conditions of St. Petersburg, we will conduct a thermal calculation of the enclosing structures.

Determine the thermal resistance of keramzit concrete panel:

$$
\mathrm{R}_{0}=\mathrm{R}_{i n t}+\mathrm{R}_{\mathrm{ext}}+\sum \mathrm{R}_{\mathrm{i}}=\frac{1}{23}+\frac{1}{8.7}+\frac{0.4}{0.25}=1.76 \quad \frac{\mathrm{m}^{2} \cdot{ }^{\circ} \mathrm{C}}{\mathrm{W}}
$$

where $R_{\text {int }}$ is the resistance to heat transfer on the inner surface of the wall, $\left(\mathrm{m}^{2} \cdot{ }^{\circ} \mathrm{C}\right) / \mathrm{W}$,

$\mathrm{R}_{\text {ext }}$ is the resistance to heat transfer on the outer surface of the wall, $\left(\mathrm{m}^{2} \cdot{ }^{\circ} \mathrm{C}\right) / \mathrm{W}$,

$\Sigma R_{i}$ is the sum of thermal resistances of all layers of the enclosing structure, $\left(\mathrm{m}^{2} \cdot{ }^{\circ} \mathrm{C}\right) / \mathrm{W}$.

$$
R_{i n t}=\frac{1}{\alpha_{i n t}}
$$


where $\alpha_{\text {int }}$ is the heat transfer coefficient of the inner wall surface, $\mathrm{W} /\left(\mathrm{m}^{2} \cdot{ }^{\circ} \mathrm{C}\right)$.

$$
R_{e x t}=\frac{1}{\alpha_{e x t}}
$$

where $\alpha_{\text {ext }}$ is heat transfer coefficient of the outer wall surface, $\mathrm{W} /\left(\mathrm{m}^{2} \cdot{ }^{\circ} \mathrm{C}\right)$

Thermal engineering analysis showed that the thermal resistance of the wall is $\mathrm{R}_{0}=1.76\left(\mathrm{~m}^{2} \cdot{ }^{\circ} \mathrm{C}\right) / \mathrm{W}$, which is much lower than the required $\left(\mathrm{R}_{\text {req }}=3.08\left(\mathrm{~m}^{2} \cdot{ }^{\circ} \mathrm{C}\right) / \mathrm{W}\right) . \mathrm{In}$ connection with the revealed discrepancy, it is necessary to additionally warm the external walls of the housing project under consideration.

Determine the minimum allowable (required) thermal resistance of the insulating material:

$$
\mathrm{R}_{\mathrm{yT}}^{\mathrm{req}}=\mathrm{R}_{\text {req }}-\left(\mathrm{R}_{\text {int }}+\mathrm{R}_{\text {ext }}+\sum \mathrm{R}_{\mathrm{i}}\right)=3.08-1.76=1.32 \quad \frac{\mathrm{m}^{2} \cdot{ }^{\circ} \mathrm{C}}{\mathrm{W}}
$$

To date, there are many options for insulation. Using the example of "ISOVER Warm Walls" (thermal conductivity coefficient $\lambda=0.036 \mathrm{~W} /\left(\mathrm{m} \cdot{ }^{\circ} \mathrm{C}\right)$ ), we determine the thickness of the insulation that will provide the required thermal resistance of the wall:

$$
\delta_{\text {ins }}^{\text {req }}=\lambda_{\text {ins }} \cdot \mathrm{R}_{\text {ins }}^{\text {req }}=0.036 \cdot 1.32=0.048 \mathrm{~m}=48 \mathrm{~mm}
$$

Insulation "ISOVER Warm walls" is available in the form of plates with a minimum thickness of 50 and $100 \mathrm{~mm}$. Determine the thermal resistance of the wall from the condition that the thickness of the insulation will be equal to $50 \mathrm{~mm}$ :

$$
\mathrm{R}_{0}^{\text {ins }}=\mathrm{R}_{\text {int }}+\mathrm{R}_{\text {ext }}+\sum \mathrm{R}_{\mathrm{i}}^{\text {ins }}=\frac{1}{8.7}+\frac{1}{23}+\frac{0.4}{0.25}+\frac{0.05}{0.036}=3.15 \frac{\mathrm{m}^{2} \cdot{ }^{\circ} \mathrm{C}}{\mathrm{W}}
$$

From the result obtained, it can be seen that $\mathrm{R}_{0}=3.15\left(\mathrm{~m}^{2 .}{ }^{\circ} \mathrm{C}\right) / \mathrm{W}>\mathrm{R}_{\text {req }}=3.08\left(\mathrm{~m}^{2} \cdot{ }^{\circ} \mathrm{C}\right) / \mathrm{W}$,

\begin{tabular}{|c|c|c|c|c|c|}
\hline No & Insulation & $\begin{array}{l}\text { Coefficient of } \\
\text { thermal con- } \\
\text { ductivity }(\lambda), \\
W /\left(\mathbf{m}^{2} \cdot{ }^{\circ} \mathbf{C}\right)\end{array}$ & $\begin{array}{l}\text { Required } \\
\text { insulation } \\
\text { thickness } \\
\left(\delta_{\text {ins }}{ }^{\text {req }}\right), \mathbf{m}\end{array}$ & $\begin{array}{l}\text { Cost of } 1 \\
\text { m2 of } \\
\text { insulation } \\
\left(C_{\text {ins }}\right), \text { rub. }\end{array}$ & $\begin{array}{l}\text { Thermal } \\
\text { resistance of the } \\
\text { wall with } \\
\text { insulation } \\
\left(\mathrm{m}^{2} \cdot{ }^{\circ} \mathrm{C}\right) / \mathrm{W} \\
\end{array}$ \\
\hline 1 & $\begin{array}{l}\text { KNAUF Ecoroll Ekstra } \\
\text { Plita }\end{array}$ & 0.037 & 0.049 & 66 & \\
\hline 2 & $\begin{array}{l}\text { KNAUF TeploKnauf } \\
\text { Nord }\end{array}$ & 0.035 & 0.046 & 97 & 3.19 \\
\hline 3 & ISOROC Ul'tralayt L & 0.038 & 0.050 & 165 & 4.39 \\
\hline 4 & ISOROC Isofas 140 & 0.035 & 0.046 & 262 & 3.19 \\
\hline 5 & ISOROC Isolight & 0.038 & 0.050 & 193 & 4.39 \\
\hline 6 & ISOVER Classic Plus & 0.037 & 0.049 & 128 & 4.46 \\
\hline 7 & ISOVER Profi & 0.037 & 0.049 & 134 & 4.46 \\
\hline
\end{tabular}
which exceeds the minimum allowable norms and ensures comfortable living for people.

Table 3 shows similar calculations for heaters of other brands.

Table 3. Technical and economic assessment of the use of heaters 


\begin{tabular}{|c|c|c|c|c|c|}
\hline No & Insulation & $\begin{array}{l}\text { Coefficient of } \\
\text { thermal con- } \\
\text { ductivity }(\lambda) \text {, } \\
W /\left(\mathbf{m}^{2} \cdot{ }^{\circ} \mathbf{C}\right)\end{array}$ & $\begin{array}{l}\text { Required } \\
\text { insulation } \\
\text { thickness } \\
\left(\delta_{\text {ins }}{ }^{\text {req }}\right), \mathrm{m}\end{array}$ & $\begin{array}{l}\text { Cost of } 1 \\
\text { m2 of } \\
\text { insulation } \\
\left(C_{\text {ins }}\right) \text {, rub. }\end{array}$ & $\begin{array}{l}\text { Thermal } \\
\text { resistance of the } \\
\text { wall with } \\
\text { insulation }{ }^{1}\left(\mathrm{R}_{0}{ }^{\mathrm{i}}\right) \text {, } \\
\left(\mathrm{m}^{2 .}{ }^{\circ} \mathrm{C}\right) / \mathrm{W}\end{array}$ \\
\hline 8 & ISOVER Warm walls & 0.036 & 0.048 & 85 & 3.15 \\
\hline 9 & $\begin{array}{l}\text { ISOVER Warm Home } \\
\text { Plita }\end{array}$ & 0.038 & 0.050 & 123 & 4.39 \\
\hline 10 & ROCKWOOL Rokfasad & 0.037 & 0.049 & 286 & 3.11 \\
\hline 11 & $\begin{array}{l}\text { ROCKWOOL Fasad } \\
\text { Batts }\end{array}$ & 0.037 & 0.049 & 318 & 3.11 \\
\hline 12 & $\begin{array}{l}\text { ROCKWOOL Light } \\
\text { Batts }\end{array}$ & 0.036 & 0.048 & 108 & 3.15 \\
\hline 13 & PAROC eXtra & 0.036 & 0.048 & 95 & 3.15 \\
\hline 14 & PAROC eXtra Light & 0.038 & 0.050 & 162 & 4.39 \\
\hline 15 & PAROC eXtra Smart & 0.036 & 0.048 & 100 & 3.15 \\
\hline 16 & URSA Universal & 0.036 & 0.048 & 58 & 3.15 \\
\hline 17 & URSA Terra & 0.036 & 0.048 & 64 & 3.15 \\
\hline 18 & URSA Geo P-15 & 0.037 & 0.049 & 60 & 3.11 \\
\hline 19 & URSA PureOne 34PN & 0.034 & 0.045 & 113 & 3.23 \\
\hline 20 & URSA PureOne 37RN & 0.037 & 0.049 & 84 & 3.11 \\
\hline 21 & ECOVER Light 30 & 0.037 & 0.049 & 78 & 3.11 \\
\hline 22 & $\begin{array}{l}\text { ECOVER Light } \\
\text { Universal }\end{array}$ & 0.037 & 0.049 & 84 & 3.11 \\
\hline 23 & $\begin{array}{l}\text { ECOVER Ecofasad } \\
\text { Optima }\end{array}$ & 0.035 & 0.046 & 241 & 3.19 \\
\hline 24 & PENOPLEX Wall & 0.032 & 0.042 & 280 & 3.32 \\
\hline 25 & PENOPLEX Comfort & 0.03 & 0.040 & 217 & 3.09 \\
\hline 26 & $\begin{array}{l}\text { TECHNONICOL Rock } \\
\text { light }\end{array}$ & 0.04 & 0.053 & 170 & 4.26 \\
\hline 27 & Master Therm PSB-S-15 & 0.043 & 0.057 & 229 & 4.09 \\
\hline 28 & Master Therm PSB-S-25 & 0.041 & 0.054 & 292 & 4.20 \\
\hline 29 & Master Therm PSB-S-35 & 0.038 & 0.050 & 410 & 4.39 \\
\hline 30 & BASWOOL Standard 50 & 0.038 & 0.050 & 207 & 4.39 \\
\hline 31 & BASWOOL Fasad 110 & 0.038 & 0.050 & 436 & 4.39 \\
\hline 32 & BASWOOL Fasad 120 & 0.038 & 0.050 & 473 & 4.39 \\
\hline
\end{tabular}

Note:

${ }^{1}$ For calculations, the closest standard size of insulation (not less than the required thickness) produced by manufacturers was used.

\section{Results}

All military towns in our country are owned by the Ministry of Defense of the Russian Federation or by municipal or regional property. To carry out a major overhaul or renovation of buildings and structures, there is no need to attract borrowed (credit) funds. Often, military towns adopted on the balance of local authorities, which have housing and engineering infrastructure, are included in regional development programs. For this reason, when calculating 
the return on investment in thermal insulation of facades, only budget funds will be taken into account (without borrowing funds).

Using the example of a residential house of KPD-4570 series (modification of 1989), we will determine the payback period for investments in facade insulation.

To calculate the projected discounted payback period of investments in additional insulation of facades, we will use the formula:

$$
\mathrm{T}_{\mathrm{D}}=\frac{\ln \left(1+\frac{\Delta \mathrm{K}}{\Delta \mathrm{E}} \cdot \frac{\mathrm{r}-\mathrm{i}}{1+\mathrm{i}}\right)}{\ln \left(\frac{1+\mathrm{r}}{1+\mathrm{i}}\right)},
$$

where TD is estimated discounted payback period, year;

$\Delta \mathrm{K}$ is the difference in capital costs for the construction of insulated and basic options for the exterior walls (facades) of a building, rub.;

$\Delta \mathrm{E}$ is the difference between the losses of thermal energy through the outer enclosing structures before and after insulation, rub;

$r$ is average annual growth in the cost of heat tariffs;

$\mathrm{i}$ is discount rate.

The calculation of the payback of thermal insulation of the facades of the building will be based on the example of ISOROC Izolight insulation, the cost of which $1 \mathrm{~m}^{2}$ is closest to the average cost of insulation samples shown in Table 3.

Capital costs for additional insulation of $1 \mathrm{~m}^{2}$ of the outer wall of an existing building are equal to $1,823 \mathrm{rubles} / \mathrm{m}^{2}$ :

- $193 \mathrm{rub} / \mathrm{m}^{2}$ - the cost of insulation "ISOROC Isolight" $100 \mathrm{~mm}$ thick,

- $120 \mathrm{rub} / \mathrm{m}^{2}$ - fasteners and guides;

- $300 \mathrm{rub} / \mathrm{m}^{2}$ - dry building mixes;

- $1,210 \mathrm{rub} / \mathrm{m}^{2}$ - the cost of the full cycle of construction and installation works.

The annual cash savings achieved as a result of work on the insulation of building facades are determined by the formula:

$$
\Delta \mathrm{E}=\left(\mathrm{V}_{1}-\mathrm{V}_{2}\right) \frac{0.024 \cdot \mathrm{D}_{\mathrm{d}}}{1163} \cdot \mathrm{c}_{\mathrm{T}}
$$

In our case, the heat transfer coefficient of external walls before using heat insulation $\left(\mathrm{V}_{1}\right)$ is equal to:

$$
\mathrm{V}_{1}=\frac{1}{\mathrm{R}_{0}}=\frac{1}{1.76}=0.57 \quad \frac{\mathrm{W}}{\mathrm{m}^{2} \cdot{ }^{\circ} \mathrm{C}}
$$

The required (normalized) heat transfer resistance for the external walls of residential buildings in relation to the climatic conditions of St. Petersburg is $R_{\text {req }}=3.08\left(\mathrm{~m}^{2} \cdot{ }^{\circ} \mathrm{C}\right) / \mathrm{W}$, which corresponds to the heat transfer coefficient $\mathrm{V}_{2}$ :

$$
\mathrm{V}_{2}=\frac{1}{\mathrm{R}_{\text {req }}}=\frac{1}{3.08}=0.325 \frac{\mathrm{W}}{\mathrm{m}^{2} \cdot{ }^{\circ} \mathrm{C}}
$$


Taking into account the fact that in the current year the cost of heat energy $\left(\mathrm{c}_{\mathrm{T}}\right)$ is set at $1,775.45$ rubles / Gcal, the amount of reduction in operating costs for the first heating period as a result of the introduction of energy-saving measures will be $43.05 \mathrm{rubles} / \mathrm{m}^{2}$.

$$
\begin{aligned}
& \Delta \mathrm{E}=\left(\mathrm{V}_{1}-\mathrm{V}_{2}\right) \frac{0.024 \cdot \mathrm{D}_{\mathrm{d}}}{1163} \cdot \mathrm{c}_{\mathrm{T}}= \\
& =(0.57-0.325) \frac{0.024 \cdot 4796}{1163} \cdot 1775.45=43.05 \quad\left(\frac{\mathrm{rub} .}{\mathrm{m}^{2}}\right)
\end{aligned}
$$

From 2008 to 2019, the average value of the relative growth of tariffs for thermal energy in St. Petersburg was $10.73 \%$ per year (see Table 4). Thus, the average annual growth of tariffs for thermal energy is assumed to be 0.1073 .

Table 4. Dynamics of growth of tariffs for thermal energy in St. Petersburg in 2008-2019

\begin{tabular}{lll}
\hline Year & Tariff for thermal energy, rub / Gcal & $\begin{array}{l}\text { The increase in the cost of thermal } \\
\text { energy in the previous year }\end{array}$ \\
\hline 2008 & 650.00 & - \\
2009 & 795.73 & $+22.4 \%$ \\
2010 & 931.00 & $+17.0 \%$ \\
2011 & $1,050.00$ & $+12.8 \%$ \\
2013 & $1,175.00$ & $+11.9 \%$ \\
2014 & $1,351.25$ & $+15.0 \%$ \\
2015 & $1,408.01$ & $+4.20 \%$ \\
2016 & $1,541.78$ & $+9.50 \%$ \\
2017 & $1,621.95$ & $+5.20 \%$ \\
2018 & $1,678.72$ & $+3.50 \%$ \\
2019 & $1,775.45$ & $+5.76 \%$ \\
\hline
\end{tabular}

Discounting of the future cash flows will be done at the refinancing rate of the Central Bank of the Russian Federation (7.5\%), that is, when calculating the payback period of investment, we will take the parameter i equal to 0.075 .

Thus, the payback period of investments in the insulation of building facades with the existing growth of tariffs for thermal energy will be 27.7 years:

$$
\mathrm{T}=\frac{\ln \left(1+\frac{\Delta \mathrm{K}}{\Delta \mathrm{E}} \cdot \frac{\mathrm{r}-\mathrm{i}}{1+\mathrm{i}}\right)}{\ln \left(\frac{1+\mathrm{r}}{1+\mathrm{i}}\right)}=\frac{\ln \left(1+\frac{1823}{43.05} \cdot \frac{0.1073-0.075}{1+0.075}\right)}{\ln \left(\frac{1+0.1073}{1+0.075}\right)}=27.7 \text { years }
$$

For comparison, if you take the cheapest of the considered samples of insulation ("URSA Universal", $\lambda=0.036, \delta=0.05 \mathrm{~m}, \mathrm{C}_{\mathrm{ins}}=58 \mathrm{rubles} / \mathrm{m}^{2}$ ), then the payback period will be 26.3 years. 


\section{Conclusions}

Despite the fact that the Ministry of Defense of the Russian Federation is actively engaged in the arrangement of new military towns, a large part of the existing residential development is an old fund that has long been in need of repair and reconstruction, taking into account the existing requirements for energy efficiency (thermal protection of buildings). An example of this are series of residential development of military towns is KPD-4570 series.

The efficiency of energy-saving measures is characterized by the projected payback period, which is calculated taking into account the forecast growth in heat tariffs, discounting of future cash flows and, of course, the cost of the insulation work themselves. In the event that the payback period is less than the predicted durability (operational life) of the adopted constructive decision, it can be considered economically viable.

\section{References}

1. N. A. Skorikova, History of planning and development of the military town number 19 in Irkutsk. In: News of the laboratory of ancient technologies, 1(22), 132-147 (2017)

2. M. R. Petrichenko, E. V. Kotov, D. V. Nemova, D. S. Tarasova, V. V. Sergeev, Numerical simulation of ventilated facades under extreme climate conditions. In: Magazine of Civil Engineering, 1(77), 130-140 (2018)

3. D. D. Zaborova, M. I. Kukolev, M. T. Mussorina, M. R. Petritchenko, The simplest mathematical model of the energy efficiency of layered building envelopes. In: St. Petersburg polytechnic university journal of engineering science and technology, 4 (254), 28-33 (2016)

4. T. A. Musorina, O. S. Gamayunova, M. R. Petrichenko, Thermal regime of enclosing structures in high-rise buildings, 8(119), 935-943 (Vestnik MGSU, 2018)

5. T. A. Musorina, O. S. Gamayunova, M. R. Petrichenko, Substantiation of design measures to increase energy efficiency of exterior walls, 11(110), 1269-1277 (Vestnik MGSU, 2017)

6. A. S. Gorshkov, N. I. Vatin, P. P. Rymkevich, O. O. Kydrevich, Payback period of investments in energy saving, Magazine of Civil Engineering. 2(78), 65-75 (2018)

7. E. A. Statsenko, A. F. Ostrovaia, T. A. Musorina, M. I. Kukolev, M. R. Petritchenko, The elementary mathematical model of sustainable enclosing structure, Magazine of Civil Engineering, 8(68), 86-91 (2016)

8. N. I. Vatin, A. Y. Ivanov, Y. L. Rutman, S. A. Chernogorskiy, Earthquake engineering optimization of structures by economic criterion, Magazine of Civil Engineering, 8(76), 67-83 (2017)

9. E. A. Martynenko, A. A. Staritcyna, V. A. Rybakov Reconstruction of the Residential District of St. Petersburg Historic Center, Construction of Unique Buildings and Structures, 1(40), 32-42 (2016)

10. E. Gumerova, O. Gamayunova, T. Meshcheryakova, Energy efficiency upgrading of enclosing structures of mass housing of the soviet union, Advances in Intelligent Systems and Computing, 692, 432-439 (2018)

11. V. I. Malyuk, A. E. Radaev, G. Yu. Silkina, Procedure for determining the characteristics for development of industrial enterprises using optimization modeling tools. In: St. Petersburg State Polytechnical University Journal. Economics, 11(6), 195-211 (2018) 
12. A. E. Radaev, V. V. Kobzev, Optimizing the configuration for the supply network of industrial enterprises based on the probabilistic process model. In: St. Petersburg State Polytechnical University Journal. Economics, 6(256), 166-178 (2016)

13. N. I. Vatin, V. Z. Velichkin, G. L. Kozinets, V. I. Korsun, V. A. Rybakov, O. V. Zhuvak, Precast-monolithic reinforced concrete beam-slabs technology with claydit blocks, Construction of Unique Buildings and Structures, 7(70), 43-59 (2018) 